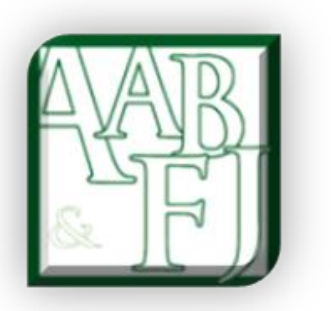

\title{
Sustainable Development Goals and Businesses
}

\section{Editors}

\author{
Dr. Hima Bindu Kota \\ Prof. (Dr.) Gurinder Singh \\ Prof. Monir Mir \\ Dr. Ciorstan Smark \\ Prof. Bhawna Kumar
}

The unprecedented crisis caused by Covid-19 has united the world in its pain and suffering. All countries (some countries more than others) are affected by this pandemic created by the novel coronavirus, and it has become evident that countries have to work together in collaboration and cooperation to emerge victoriously. Businesses cannot now consider short term profits only, but need to take into account people and the planet. The Sustainable Development Goals (SDGs), with 17 goals at its heart, is one such initiative that emerged at the United Nations Conference on Sustainable Development in Rio de Janeiro in 2012, the purpose of which was to produce a set of universal goals that would help combat the urgent environmental, political and economic challenges projected to face our world by 2030 . These goals have the potential to become a powerful political vision that can support the urgently needed global transition to shared and lasting prosperity.

In view of the limited effectiveness of intergovernmental efforts, and questions about the capacity of national governments to effect change, the Sustainable Development Goals (SDGs) need to mobilise new agents of change such as businesses, cities and civil society. In order to galvanise this broad set of actors, multiple perspectives on sustainable development are needed that respond to the various motives and logics of change of these different actors. Sustainable Development Goals (SDGs) cannot be, and should not be, only the responsibility of governments around the world. It has to be a collaborative effort of all stakeholders such as businesses, cities and civil society. Therefore, to cater to the diverse requirements of these stakeholders, different and varied perspectives of sustainable development have to emerge.

In this context, this special issue aims to bring out these multiple perspectives of sustainable development and SDGs. A better and a more sustainable future is also the responsibility of businesses, and this special issue explores how businesses act as change agents and focuses on some of the prescribed 17 Sustainable Development Goals, especially the SDG 5- Gender Equality; SDG8 - Decent Work and Economic Growth; and - SDG 12 - Responsible Consumption And Production.

The first paper by Tewari, Singh and Julka (2021) discusses the concept of impact investing in the context of SDGs, using the impact value chain and indicators developed on the basis of 
SDGs targets and indicators, to create a link between SDGs and indicators based on visualised outcome and impact. The second paper by Singh et al. (2021) focuses on the sustainable development goal of gender diversity and analyses its role in corporate social responsibility. The paper uses the Board Capital Theory, which advocates that the appointment of women directors on board may enhance various dimensions of the board capital breadth and help in better decision making, linking the research with the gender diversity SDG. Goel, Singh, Kota. Mir and Smark (2021) explore the eighth goal of sustainable development of economic growth, in the third paper of this special issue, and analyses the role of international investments like FDI and FII and finds that such investments contribute to industrial production, foreign exchange reserves and sustainable growth of BRICS economies. The fourth paper by Gupta and Jhamb (2021) attempts to throw light on green financing and investigates the performance of green and non-green portfolios during crisis periods, further examining the impact of market cycles on the returns of these portfolios. It has been observed that green portfolios are outperforming market after the passing of any crisis, as Indian investors are believed to drive demand for the stock with green initiatives.

Kaur and Bhardwaj (2021), in the fifth paper of this special issue, studies the consumption of sustainable clothing in India, to predict the behaviour of Indian consumers towards such products and develop some important marketing strategies for environmentally sustainable clothing. This study is the first study which analyses the impact of "Actual behavioral control" through a scale of "Proxy measure of actual behavior" as a moderator in the PI-PB gap in the framework of the TPB for the consumption of sustainable clothing in India. The sixth paper by Khalique et al., (2021) delves into the role of Multi-National corporations (MNCs) operating out of India in incorporating workforce diversity, equal opportunity and inclusive growth of its employees by providing a decent work environment, which is SDG 8. The study focuses on nine multi-national corporations (MNCs), having headquarters in the United States of America and Europe and operating as subsidiaries in Delhi, NCR, and reveals that workforce diversity is prevalent in these MNCs and can act as a benchmark for Indian companies for implementing workforce diversity in their operations. This will lead to achieving not only business goals, but also help in building a better economy for the country.

This special issue has been bought out amidst global pandemic of coronavirus and we would like to thank all the authors and peer reviewers that helped to make this issue possible.

\section{References}

Goel, Nisha; Singh, Gurinder; Kota, Hima Bindu; Mir, Monir; and Smark, Ciorstan, Sustainable Development Goals and Economic Growth in Emerging Economies: A Study of Sustainability through International Investments, Australasian Accounting, Business and Finance Journal, 15(5), 2021, 41. doi: http://dx.doi.org/10.14453/aabfj.v15i5.4

Gupta, Lovleen and Jham, Juhi, Green Investing: Impact of pro-environmental preferences on stock market valuations during turbulent periods, Australasian Accounting, Business and Finance Journal, 15(5), 2021, 59-81. doi: http://dx.doi.org/10.14453/aabfj.v15i5.5 
Kaur, Jaspreet and Bhardwaj, Neha, Their Control will Make or Break the Sustainable Clothing Deal-A Study of the Moderating Impact of Actual Behavioural Control on the Purchase Intention-Behaviour Gap for Sustainable Clothing in India, Australasian Accounting, Business and Finance Journal, 15(5), 2021, 59. doi: http://dx.doi.org/10.14453/aabfj.v15i5.6

Khalique, Fehmina; Madan, Poornima; Puri, Geetika; and Parimoo, Daleep, Incorporating SDG 8 for Decent Work Practices: A study of MNC Subsidiaries in India, Australasian Accounting, Business and Finance Journal, 15(5), 2021, 99-114. doi: http://dx.doi.org/10.14453/aabfj.v15i5.7

Singh, Amit Kumar; Kota, Hima Bindu; Sardana, Varda; and Singhania, Shubham, Does Gender Diversity on Board Promote Corporate Social Responsibility? An Empirical Analysis of Sustainable Development Goals, Australasian Accounting, Business and Finance Journal, 15(5), 2021, 22-40. doi: http://dx.doi.org/10.14453/aabfj.v15i5.3

Tewari, Seema; Singh, Harjit; Wadhwa, Shobhit; and Tandon, Deepak, Scaling Impact Investment for Sustainable Development Goals: An Empirical Analysis, Australasian Accounting, Business and Finance Journal, 15(5), 2021, 4-21. doi: http://dx.doi.org/10.14453/aabfj.v15i5.2 